\title{
Kidney Cancer Pathologic TNM Finding v6
}

National Cancer Institute

\section{Source}

National Cancer Institute. Kidney Cancer Pathologic TNM Finding v6. NCI Thesaurus. Code C63556.

A pathologic finding about one or more characteristics of kidney cancer, following the rules of the TNM AJCC v6 classification system. 